OPEN ACCESS

Edited by:

Claudia Tanja Mierke,

Leipzig University, Germany

Reviewed by:

Wei Chen,

Stanford University, United States

*Correspondence:

Jiong Lin

1150692210@qq.com

Specialty section:

This article was submitted to

Cell Adhesion and Migration,

a section of the journal

Frontiers in Cell and Developmental

Biology

Received: 08 March 2021

Accepted: 23 March 2021

Published: 13 April 2021

Citation:

Lin J (2021) Commentary: Anti-tumor

Effect of Oleic Acid in Hepatocellular

Carcinoma Cell Lines via Autophagy

Reduction

Front. Cell Dev. Biol. 9:677595. doi: 10.3389/fcell.2021.677595

\section{Commentary: Anti-tumor Effect of Oleic Acid in Hepatocellular Carcinoma Cell Lines via Autophagy Reduction}

\author{
Jiong Lin* \\ Department of Oncology, Affiliated Hospital of Guangdong Medical University, Zhanjiang, China
}

Keywords: oleic acid, hepatocellular carcinoma, invasion, cell death, migration

\section{A Commentary on}

Anti-tumor Effect of Oleic Acid in Hepatocellular Carcinoma Cell Lines via Autophagy Reduction

by Giulitti, F., Petrungaro, S., Mandatori, S., Tomaipitinca, L., de Franchis, V., D’Amore, A., et al. (2021). Front. Cell Dev. Biol. 9:629182. doi: 10.3389/fcell.2021.629182

Recently, we read a paper in Frontiers in Cell and Developmental Biology "Anti-tumor Effect of Oleic Acid in Hepatocellular Carcinoma Cell Lines via Autophagy Reduction.” Oleic Acid (OA) may be a promising drug candidate for the treatment of hepatocellular carcinoma (HCC). However, some problems existing in this paper need to be commented.

With great interest we read a paper "Anti-tumor Effect of Oleic Acid in Hepatocellular Carcinoma Cell Lines via Autophagy Reduction" published in Frontiers in Cell and Developmental Biology (Giulitti et al., 2021). Blocking autophagy suppresses the growth of HCC cells (Zai et al., 2020). Authors indicated that OA induced cell death and reduced migration and invasion of the HCC cells, suggesting OA could be a promising drug candidate for the treatment of disease. However, some issues existing in this paper need to be commented.

In the paper, OA inhibited the invasion and migration of HCC cells after treatment with OA $(300 \mu \mathrm{M})$ for $48 \mathrm{~h}$ (Figure 6). However, authors demonstrated that OA significantly suppressed cell proliferation and induced cell death of HCC cells after incubation with the same concentrations $(300 \mu \mathrm{M})$ of $\mathrm{OA}$ for the same time $(48 \mathrm{~h})$ (Figures $3-5)$. These results strongly suggested that the cause responsible for inhibition of migration and invasion of cells could be due to apoptosis induction of OA. Authors could treat the cells with OA at a lower concentration or for a short time when studying the inherent effects of drugs on the migration and invasion ability of cells without apoptosis induction. This made the results more convincing.

\section{AUTHOR CONTRIBUTIONS}

JL: study concept and design, data analysis, methodology, drafting manuscript, review and editing, and supervision. 


\section{REFERENCES}

Giulitti, F., Petrungaro, S., Mandatori, S., Tomaipitinca, L., de Franchis, V., D'Amore, A., et al. (2021). Anti-tumor effect of oleic acid in hepatocellular carcinoma cell lines via autophagy reduction. Front. Cell Dev. Biol. 9:629182. doi: 10.3389/fcell.2021.629182

Zai, W., Chen, W., Han, Y., Wu, Z., Fan, J., Zhang, X., et al. (2020). Targeting PARP and autophagy evoked synergistic lethality in hepatocellular carcinoma. Carcinogenesis 41, 345-357. doi: 10.1093/carcin/bg z104
Conflict of Interest: The author declares that the research was conducted in the absence of any commercial or financial relationships that could be construed as a potential conflict of interest.

Copyright $\odot 2021$ Lin. This is an open-access article distributed under the terms of the Creative Commons Attribution License (CC BY). The use, distribution or reproduction in other forums is permitted, provided the original author(s) and the copyright owner(s) are credited and that the original publication in this journal is cited, in accordance with accepted academic practice. No use, distribution or reproduction is permitted which does not comply with these terms. 